\title{
Innovative Marketing and Its Impact on Customers' Value Creation in Orange Jordan Telecom
}

\author{
Dr. Sultan Mohammad Said Sultan Freihat \\ Dr. Diana Moh'd Adnan Homsi \\ Dr. Tareq N. Hashem \\ Marketing Department, \\ Isra University, \\ Amman, Jordan
}

DOI: https://doi.org/10.36941/ajis-2020-0103

\begin{abstract}
The purpose of this study was to provide an analytical presentation of the impact of innovative marketing in creating value for Orange Jordan Telecom customers and to identify the extent to which the elements of the innovative marketing mix impact the value creation of the customer. The researchers adopted two sources to collect data for this study: Secondary data, included, references, literature, and relevant periodicals to the study to clarify basic concepts, types, and areas of innovative marketing, and to identify the most important and relevant previous studies to the subject, while the second was a field study included: design and distribution of a questionnaire to collect data from Orange Jordan Telecom Customers'. The questionnaire has been distributed to a random sample of (9o) customers who deal with different orange branches for more than three years. Total of (65) valid questionnaires were retrieved and analyzed, with a percentage of (72\%). The reliability test ratio of both the independent and dependent variables were $(82 \%)$. The populations of the study were Orange Jordan Telecom Customers. The main findings of the study were as follows: There is a statistically significant impact of innovative marketing on creating value for Orange Jordan Telecom customers. There is a statistically significant impact of each one of the innovative marketing dimensions (innovation in marketing mix elements: innovation in product, innovation in price, innovation in promotion, and innovation in distribution) on creating value for Orange Jordan Telecom customers.
\end{abstract}

Keywords: innovative marketing, innovation in product, innovation in price, innovation in promotion, Innovation in distribution

\section{Introduction}

In light of the emerging realities which created by the economic globalization of the explosion and the acceleration of knowledge and technological development, competition among economic institutions to meet the needs of consumers and gain their loyalty has intensified in a way that guarantees continuity and allows them to survive and grow in the market, not only in the short term but also in the long term. In the context of these competition conditions, and the dynamic nature of the current markets which requires the organization to be vigilant enough to keep pace with the changes and developments in its environment to ensure growth and continuity. The importance of 
innovative marketing comes into view as an input or as an effective strategic tool not only to satisfy customers' needs and desires in better ways, but also to discover desires they were unable to express, and looking for innovative ways to create value for them. By this way the institution supports its competitiveness and its great role in activating its marketing performance, by creating a suitable marketing mix for all customers and access to new goods, Prices, promotion, and distribution, which positively affects the development of the organization's sales, growth of its market share, win the satisfaction of customers and loyalty, thus enhancing its competitive position in the market.

\section{Essentials on Innovative Marketing}

Innovative marketing has been and continues to be the focus of academics and marketing practitioners because it has a positive impact on the economic success of the organization and its overall success in achieving efficiency and effectiveness on one hand and ensuring competitive advantage to defend its strategic position on the other hand. The following are some theoretical concepts of innovative marketing, its importance, types, and stages.

\section{Definition of Innovative Marketing}

The definitions of innovative marketing presented by the researchers in the field of marketing varied according to their points of view. It is defined as: "The ability to deliver as many products as possible faster than competitors to increase market share(Hill \& Gareth, 2010,p:224). Lambin defined innovative marketing as: "Developing new or unconventional ideas in marketing practices. It affects all activities related to directing the product from producer to end-user' (Lambin, 2009,p281). Innovative marketing is also known as: "Successful exploitation of new ideas and may focus on the product element whether it is a good or service, a price element, a promotion element, a distribution element, or all of these elements at the same time" (Buraq\& Lahrash, 2016, p:o1). Some know innovative marketing as: "Providing the necessary capabilities to produce new products by building intellectual groups to achieve a competitive advantage, or the ability of the organization to create value and increase its financial and technical capabilities through the creation of new products or production lines that contribute to reducing costs and improve the existing products or find new ways to promote and market them "(Al-Dowa\& Al-Muhtadi, 2015, p13). Thus, any unique action in marketing that makes the organization different from the others in the market can be classified within the field of innovative marketing.

Through the above definitions, it can be said that innovative marketing is the design and implementation of creative, and non-traditional ideas, and transforming them into practical applications in one of the areas of marketing mix such as product, price, promotion, and distribution. Thus, innovative marketing has several characteristics, the most important of them are:

1. Create new ideas, study them, demonstrate their usefulness, and work to apply them.

2. Work to exploit new ideas efficiently and effectively to maximize the expected benefit.

3. Innovative marketing includes one or more of the marketing mix components.

\section{Importance of Innovative Marketing}

Innovative Marketing is of great importance to the organizations that use it, to the customers who benefit from it, and to the community in general (Michael\& Galanakist, 2014, pp: 12, 13):

\subsection{Importance for organizations.}

Innovative Marketing achieves a distinct competitive advantage of the organization by distinguishing its mental image, reputation, from other competitor's mental image and reputation the existence of such a feature has its positive results of the organization in maintaining or increasing its market 
share, increasing its sales, profits and the possibility to reach the center of market leadership, gain and attract new customers and retain existing customers. Of course, the more innovative marketing can create a competitive advantage, the longer it will be possible to reap the benefits.

\subsection{Importance for customers}

Innovative marketing achieves customers, whether they are organizations or individuals, many benefits, which may take the form of satisfying needs that were not saturated or satisfied before, satisfying current needs better than before, and saving on expenses.

\subsection{Importance for society}

The benefits of innovative marketing are reflected at the level of the organizations that use it, the customers whom this type of marketing directed to, and the society in general, through its contribution in raising the standard of living and increasing gross national product, especially if applied in the field of international marketing, which helps the state to face the competition in the international market, and the provision of foreign currencies that are needed by developing countries in particular.

\section{Types of Innovative Marketing}

One of the most common classifications classified innovative marketing into four types: product type, type of organization, the objective of innovation, and target customer. Below is a brief description of them (Abu Jumaa, 2011):

\subsection{Classification by product type}

According to the broad concept of marketing the product can be a good, a service, an organization, a person, or an idea, and for this reason, innovative marketing can be in the area of goods, services, organizations, people, or ideas. The primary objective of innovative marketing, and the form it takes, can be greatly influenced by the type of the product focused on.

\subsection{Classification by type of organization}

Innovative marketing can be divided according to the organization's primary objective, whether it's a profit-making or non-profit organization. It can be divided by its basic activity: (industrial organization, a trade organization, service organization, etc.) .other bases also can be used in the division, such as the type of ownership. As a result, the innovative marketing that fits a particular organization may not be suitable for another organization, vice versa.

\subsection{Classification by Objective}

Innovative marketing is divided by the objective into the one, aimed at solving a specific problem facing the organization, such as sales decline, or maybe aimed at improving performance. Therefore, innovative marketing in the first case is a reaction, while in the latter case is an initial one. The organization may combine two kinds of innovative marketing if it deals with more than one product or more than one market and/or doing more than one activity, so that, there are problems in some of them, while wants to continuously improve performance in others. 


\subsection{Classification by Customer}

Innovative marketing can be divided according to the target customers to the one which directed to serve end consumers, or the other which directed to serve industrial buyers (organizations). Innovative marketing directed to end consumers usually depends more on arousing emotional (nonrational) motives than on rational motivation, and vice versa for the one directed to the industrial buyer.

\section{Innovative Marketing Dimensions}

Innovative marketing is not limited to a specific marketing area but extends to any area or marketing practice. It is based on the idea that one component of the marketing mix cannot effectively achieve goals and objectives, so mixing all components of the marketing mix will be more capable of meeting the objectives pursued by the organization (Lahul, 2008). It is certain that the product does not last long; it passes through a life cycle that determines how long it stays in the market until the emergence of problems affecting its sales. On this basis, the institution innovates in products to cope with competitive pressures, changing tastes and desires, addressing the problems related to shortterm product life technological progress or even technological obsolescence, etc. (Nagasimha, 2015).

\subsection{Innovation in Product}

The product is the main element of the marketing mix. It represents the fundamental variable in guiding all marketing decisions and maximizing the satisfaction of the consumer's needs and thus ensuring the continuity and growth of the organization. The researchers differed on the development of a specific classification of new products because they differed in defining the term, as it is relative and multidimensional, In this area. Philip Kotler introduced a classification to the new product based on the integration of two criteria: the degree of innovation for the market, and the degree of innovation for the organization, he referred to six categories (Shukal, etal, 2015, p: 4):

1. New products introduced for the first time: new to the organization, market, and customers.

2. Adding new production lines: These products are not new to the market, but new to the organization, try to add them to its production lines in order to exploit available market opportunities in certain market sectors.

3. Expansion of existing product lines: adding new products to its existing product line, where their characteristics and specifications are close to current products.

4. Improvement of existing products: The organization makes adjustments and improvements to its existing products for the purpose of reducing cost, increase customer value-added, or face market competition.

5. Product re-substitution:: In this case, The organization is working to re-locate its products in specific sectors, when discovering new uses of its products in these sectors, or to change consumer behavior.

6. New low-cost products: reduction in production or marketing costs that lead to an increase in consumer's value-added is considered a new product to the organization, and not to customers and market.

\subsection{Innovation in pricing}

Pricing is one of the most important elements of the marketing mix, it directly affects the size of the organization's expected revenue. It's also one of the most important determinants in the customer's purchasing decision making.

Methods of innovation in pricing.

Among the most important innovative methods of pricing are (Lahul, 2008): 
1. The consumer sets the price of the product himself.

This method is based on placing a clear and easy-to-read list of the prices of the products near the products on the shelves, but not on products themselves, and the buyer is asked to put the price on the product he or she would like to buy, Upon payment, the employee records the prices as written by the customer.

2. Pricing based on unit price.

According to this method, the unit price of the product is explained regardless of the size of the package size, eg: if the product is sold in three sizes $5 \mathrm{~kg}, 3 \mathrm{~kg}, 2 \mathrm{~kg}$, and its prices were respectively JD 25, JD18, and JD 14. Instead of setting previous prices, the unit price is set, and the prices placed on the products are as follows: JD 5, JD 6, and JD 7, so that the consumer can easily compare the three packages by providing additional information that enables him to make a better and easier purchasing decision and avoid misleading or conceiving (Abu Jumaa, 2011).

3. The way the organization refunds part of the cash price to the buyer instead of the traditional discount given at the time of purchase as a reduction of a certain percentage of the sale price, the organization refunds part of the cash price to the buyer by sending it by mail or other means.

4. Package pricing method.

In this way, several products are standardized and presented in the form of a package, a set of integrated goods and services, at affordable or low prices comparing with their individual prices. This helps to promote the products offered in the market by convincing customers of the benefits achieved when buying this package and increasing the volume of sales [6].

5. Peak pricing and out-of-peak pricing.

The organization sets a high peak price in the time when demand for a product or service is high (exceed supply), and low non-peak prices until the demand for the product is converted from peak time to time when demand is low (Al-Taei \& Alalak, 2008).

6. Retail at wholesale price.

In order to attract consumers to deal with, many retailers price their products and sell them to customers at a price similar to the wholesale price level (Abu Jumaa, 2011).

7. Psychological pricing.

This policy is based on an emotional and illogical effect on the consumer. Examples of this policy are the following (Abu Jumaa, 2011).;Tawfiq \& Maala, 2009):

- Fractional price policy: The products are priced here on the basis of fractions of monetary units.

- Familiar price policy: The prices the consumer is accustomed to and cannot accept to change. But since the prices of the raw materials tend to be high from time to time, it is difficult to maintain the same price of the products, which make some producers to change the weights of products and to maintain their familiar prices.

- The symbolism prices policy: This policy is to set high prices for products, to be proof of their advancement and prestige in society.

\subsection{Innovation in promotion.}

Innovation in the field of promotion is defined as: "the ability of the organization to use new and innovative intended promotional messages to the target customers by using advertising, personal selling, and other promotional mix elements, through mass and personal media to inform them about the product specification, benefits, and that it meets their needs and desires, to stimulate and convince them, in an attempt to buy it"(Mahaabat, 2009, p:264).

Innovation in promotion can be achieved through (Owsu, 2010):

- The innovative promise: the actual value of the product, or the benefits of the product the advertising message promise to deliver to the customers. 
- Confirmation of the credibility support: confirmation of the credibility of the advertising message.

- Innovative approach: whether the advertising message audible or readable, the innovative strategy must include a cheerful, dramatic, or professional tone since movement, rhythm, and distinctive color are necessary additions.

Innovation in advertising.

Successful advertising is a unique and convincing innovation. In order to achieve the objectives desired, it must be done within the framework of an integrated advertising plan within the overall promotional plan of the marketing and the organization as a whole. The goal of the advertising is to provide the recipients with information about the product in order to stimulate them to purchase. An innovative advertisement should be based on honest promises about the product and its outstanding and new performance and benefits, compared with competitors one's (Lahul, 2008).

Innovation in personal selling is used as a means to increase the likelihood of successful sales, such as innovation in obtaining information about prospective customers, and in responding to customers' objections.

\subsection{Innovation in distribution.}

Innovation can be applied in many distribution activities, in new and unfamiliar ways in the distribution of products, in the design of the distribution channel itself, in the conditions surrounding the distribution process which affects customers, and in other activities and fields (Owsu, 2010).

Some innovative methods in distribution can be found by providing the shopping cart in the supermarkets with an installed calculator so that the customer can use them to calculate the value of his purchases, automated selling is an important innovation indirect distribution, and online retailing, which has created new opportunities for sale (Abu Jumaa, 2011).

\section{Customer Value}

One of the central issues in the existence of any organization is its ability to create value for customers through producing and delivering desirable goods and services (Robert \& David, 2005). Kotler defined the value of the customer as "the difference between the total value and the total cost of the customer. The total value expresses the sum of the benefits the customer receives from the product, while the total costs are the monetary, technical, functional, and psychological costs incurred by the customer when using the product or service (Kotler \& Dubois, 2003).

\subsection{The contribution of innovative marketing in the customer value creation}

Innovative marketing anticipates and detects the new and even latent needs that customers can't express by providing and achieving solutions the customer did not think for (Abdul Hamid, 2010). From the innovative marketing point of view, innovative organizations should divide and identify the characteristics of their customers who seek to deal with innovative organizations and what distinguishes them from the rest of the customers (Al Obeidi, 2009).The division of customers from the innovative marketing point of view (Al Obeidi, 2009):

1. Cost Customer: focuses on the cost of the product upon purchasing.

2. Segmentation and Service Customer: focuses on the distinct needs with an interest in service to improve product value.

3. Innovation Customer: focuses on quality, diversity, new product, new service, new style, and modern technology. 


\subsection{Ways to create customer value}

Customer value is achieved when the benefits the customer acquired for a particular product outweighs costs that have been incurred, so the organization can create value for the customer by reducing the different costs or maximizing and strengthening the benefits obtained from the product. The following are the ways to create customer value:

1. Cost reduction

Since price is an essential element in the cost the customer incurred, organizations try to reduce the price by reducing various costs, such as facilitating access to products through an extended distribution policy or facilitating the use of products by developing a new design (kotler, etal, 2009), and the organization can reduce the Services prices that are usually included in the price, such as free delivery or free installation (kotler, 2004).

But the low price is not enough to attract customers and achieve value, as no one accepts to buy a poorly performing, bad reputation, and few advantages product, despite its low price, for this reason, the organization must strive to deliver distinct performance and high advantages products better than competitors, and convince customers that they are commensurate with their prices.

2. Increasing benefits and advantages

The organization can create value for its customers by offering more advantages and benefits in its products than competitors. Customers are more sensitive in increasing and maximizing benefits compared to the costs they incurred. The greater the benefits and advantages, the greater the value of products. The organization can increase benefits in several ways (Kotler, 2004):

- Design products and services according to customer requirements by identifying their needs, expectations, and level of performance they wish and desire. With flexible manufacturing and computer database, organizations can offer unique products that satisfy a large number of customers at the same time (Mass Customization Strategy).

- Providing more convenience to the customer by facilitating access to the products, and therefore, the organization must cover the market intensively through: exhibitions establishment, catalogs distribution, allocate more hours for customer communications, as well as faster service.

- Training and guiding customers on how to use the products. Smart organizations help their customers get the most value and benefit from what they provide them.

\section{The Problem of the Study}

In the current conditions, which is characterized by increasing customer bargaining power, organizations have to work to satisfy their customers in many ways, often by satisfying their needs and desires better, but even by discovering desires they haven't been able to express, to create distinctive value for them, therefore, one of the most critical organizational tasks is to look for innovative ways and means of marketing to do so. Based on the above, the following problem is clarified as follows:

Does innovative marketing impact create value for Orange Jordan Telecom customers?

To address this problem, we have crystallized the problem of the study by asking the following sub-questions:

Does innovation in product impact create value for Orange Jordan Telecom customers?

Does innovation in price impact create value for Orange Jordan Telecom customers?

Does innovation in promotion impact create value for Orange Jordan Telecom customers?

Does innovation in distribution impact create value for Orange Jordan Telecom customers? 


\section{Importance of the Study}

Through their survey of previous and related studies, the researchers didn't find any conducted study in Jordan regarding Innovative marketing and its impact on customer value creation. Hence, the importance of this study addressed the great importance of the following two points: first, it addresses innovative marketing, which is one of the most important and new marketing concepts, especially for organizations adopt customer-oriented strategies, interested in meeting customer's needs and desires. Second, with regard to customer value creation, it is known that one of the central issues in the existence of any organization is, to retain its customers, to increase its market share, and to compete successfully, is the ability to create value for the customer through producing and delivering desirable goods and services, and to anticipates and detect the new and even latent needs that customers can't express by providing and achieving solutions the customer did not think for.

\section{Objections of the Study}

The purpose of the study is to:

1. Reveal the impact of innovative marketing on customer value creation in Orange Jordan Telecom customers'.

2. Introduce the concept, types, and areas of innovative marketing.

3. Introduce the concept of customer value creation and ways to create customer value.

4. Deduce a number of recommendations with respect to the research subject.

\section{The Hypothesis of the Study}

The field study was designed to test the main hypothesis and a number of subsidiary assumptions, as follows:

\subsection{The main hypothesis}

Ho: There is no statistically significant impact of innovative marketing on creating value in OrangeJordan Telecom Customer.

\subsection{The First sub- hypothesis}

Ho1: There is no statistically significant impact of innovation in a product on creating value in Orange Jordan Telecom Customers.

\subsection{The Second sub-hypothesis}

Hoz: There is no statistically significant impact of innovation in price on creating value in Orange Jordan Telecom Customers.

\subsection{The Third sub-hypothesis}

Ho3: There is no statistically significant impact of innovation in promotion on creating value in Orange Jordan Telecom Customers.

\subsection{The fourth sub-hypothesis}

Ho4: There is no statistically significant impact of innovation in distribution on creating value in Orange Jordan Telecom Customers. 


\section{The Methodology of the Study}

\subsection{Population and Sample}

The Population of the study consists of Orange Jordan Telecom Customers. Due to the large size of the population, a random sample of (90) customers who deal with orange branches for more than three years has been selected. Where the questionnaire was distributed to them. A total of (65) valid questionnaires were retrieved and analyzed. Hence, customers can be regarded as the unit of analysis for this study.

\subsection{Data collection tools}

To collect data for the current study and its variables, a questionnaire was designed, it included (43) statement to measure the extent of which innovative marketing impact creating value in Orange Jordan Telecom Customers.

\subsection{Sources for obtaining data}

The researchers adopted two sources to collect data for this study:

1. Secondary data sources:

Included, references, literature, and periodicals relevant to the study in order to clarify basic concepts related to the study, its various dimensions, and to identify the most important and relevant previous studies on the subject.

2. Primary data sources:

The questionnaire was designed for collecting data from the customers who deal with orange branches for more than three years, about the impact of innovative marketing in creating value for Orange Jordan Telecom Customers.

\subsection{The statistical analysis methods used.}

Since the study is descriptive and analytical, the researchers employed the most appropriate statistical methods, (descriptive and inferential), that correspond with the nature of data available, for the purpose of analyzing variables and testing hypotheses of the study, they are:

1. Descriptive statistics (frequencies, mean, and standard deviations) to describe the sample responses with regard to innovative marketing dimensions.

2. Multiple regression analysis to test the hypotheses of the study (the impact of innovative marketing dimensions on customers value creation).

\subsection{Validity and reliability.}

1. (Validity) means the ability of the instrument to measure the variables that are designed to measure. The questionnaire has been introduced and judged by a number of specialists in marketing studies to ascertain the validity of the instrument.

2. Reliability of the tool: refers to the possibility of obtaining the same results if the measurement re-evaluated under the availability of similar circumstances and by using the same measurement tool. Cranach's Alpha used to determine the degree of reliability of the tool. The test result was (.81) which is higher than the acceptable limit (.6o).

\section{Previous Research}

The following is a review of the most important previous studies: 
1. The purpose of this study is to show the impressive role which innovative marketing might play in improving corporate performance, and to what extent it is one of the factors of growth, through the innovation of products, prices, promotion, and distribution. The population of the study consisted of the administrators of the Sidi Gaber Company for soft drinks. The researchers applied a comprehensive survey to administrators and their assistants. (73) Questionnaires were distributed, and (33) were analyzed. The most important findings of the study were: The degree of innovation in the institution under study is high, where the average of innovation scored (4) degree from the highest degree in the scale, which was (5). Innovation in products, whether new ones or developed ones, increased the effectiveness of other marketing activities (Amjadal, Ahmed, 2011).

2. This study aimed to determine the impact of innovative marketing on the quality of banking services dimensions (tangible aspects, reliability, responsiveness, safety, empathy) in Algeria Gulf Bank Agency. The data of the study were collected through a questionnaire designed for this purpose and distributed to the appropriate sample consisting of 62 clients selected randomly. A set of statistical methods for reaching the objectives of the study, and to test the hypotheses of the study were used. The study reached the following results: There is a significant impact of innovative marketing on the total dimensions of banking services quality; There is a significant impact of innovative marketing on the banking services dimensions (Raqeeck, 2016).

3. The study sought to clarify the role innovative marketing played in improving marketing performance of the service organization, and the extent of which it's needed, as a source of differentiation through innovation in pricing, distribution, and promotion of al - alif hotel and its role in improving marketing performance, since it seeks to achieve differentiation and leadership, and innovate new services and meet the needs of its guests, to be able to survive in a highly competitive environment in the hotel sector in the state of Ouargla. Scientific observation, documents, records, and interviews with the receptionist at the al-alif hotel have been used. The study found that innovation is of great importance, since, it introduces new services in the market, which makes the hotel distinct from its competitors. and the study also found that innovation plays a major role in improving the marketing performance indicators of the hotel (Jafour, 2016 ).

4. This study aimed to determine the role of innovation in the marketing mix as a source of competitive advantage in business organizations, through innovation in the marketing mix, and its ability to improve the organization's operations through product development and innovation in price, promotion, and distribution. So they can achieve a competitive advantage that distinguishes it from other organizations in its competitive environment. Through this study finding, the role of innovation in the marketing mix elements, in achieving added value to customers, and ascertain competitive advantage has been confirmed. It was also clear that competitive advantage can be achieved through innovation in the product by following the scientific research methods and transfer of findings to beneficial goods and services to consumers. As evidenced, achieved competitive advantage through the role of innovation in price obtained if the benefits the customer gets from the product outweigh the costs paid. While achieving competitive advantage through the role of innovation in promotion obtained by following modern methods in the promotion. The role of the innovation in distribution can be achieved when the organization use unfamiliar new ways in the distribution of products (Lahul \&Ayatt, 2017).

5. This study aimed to shed light on the promotional side of innovation and link it with customers' value creation. The sample contained (97) employees in the Algerian mobile company(Ooredoo). The most important findings were: There are weaknesses and limited use of customer communication technology, either through the use of call centers or the use of the Internet. Weak handling of customers' complaints. Lack of integrated marketing database and poor coverage of customer engagement. The research and development department in the 
institution is not independent but is affiliated to another department (Madah \& Azouz, 2018).

6. The study sought to investigate the effect of internal partnership Management on the value achieved for the customer. A default model that illustrates the correlation and impact between the independent variable internal partnership and the value of the customer has been built. Questionnaires have been distributed to the sample which consisted of (83) of the departments and divisions directors. several statistical tools to test the correlation and impact between variables such as (arithmetic means, standard deviations, simple correlation coefficient (Spearman), simple and multiple regression, and $(\mathrm{T})$ test and $(\mathrm{F})$ test, has been used. the most important conclusions were: An acceptable level of partnership with management personnel has been achieved, and this is evident through the cooperation provided by the individual worker to accomplish the work of the Organization. The company's interest in products, services, and price image among customers, for the purpose of achieving an acceptable level of value to customers(Jalab\&Khalidi, 2013).

7. The study aimed to test the quality of service, and customer value on customer satisfaction in both Islamic and commercial banks in Jordan, and the ability to face the challenges of competition among them. The study population consisted of Jordanian Islamic Banks and Jordanian commercial banks. Islamic banks were represented by Jordanian Islamic banks while commercial banks were represented by Arab Bank. An appropriate sample of (250) customers and dealers for each type of the two banks have been selected. To achieve the objectives of the study, analyze data and test hypotheses, a questionnaire with (42) statements have been designed, and lots of variety of analytical descriptive and inferential statistics means and methods used, such as standard deviations, one sample T-test, stepwise multiple regression. Findings showed a statistically significant effect on the customer value in achieving customer satisfaction in Islamic and commercial banks at a level of significance $(\alpha \leq 0.05)$.In order to identify the role of the customer value as a moderator variable, the study findings showed that there is a statistically significant effect of the banking service quality on achieving customer satisfaction in Islamic and commercial banks in Jordan with the customer value as a moderate variable at the level of $(\alpha \leq 0.05)$. The study also did not confirm the existence of statistically significant differences between Islamic and commercial banks in Jordan with respect to both customer value and customer satisfaction at the level of ( $\alpha \leq 0.05$ )(Abo Bezah, 2015).

\section{Results of the Study}

\subsection{Innovative marketing in Orange Jordan Telecom Customers}

Tables $(1,2,3,4)$ below, show us, mean, and standard deviation of the respondents' responses in terms of innovative marketing dimensions statements, in descending order.

Table (1): Mean and standard deviation of the innovation in the product dimension

\begin{tabular}{|c|l|c|c|c|}
\hline no & statement & $\begin{array}{c}\text { No of } \\
\text { respondents }\end{array}$ & Mean & $\begin{array}{c}\text { Standard } \\
\text { Deviation }\end{array}$ \\
\hline $\mathbf{1}$ & Orange continuously introduces new products into the market. & 65 & 4.1231 & 1.12511 \\
\hline $\mathbf{2}$ & Orange products are available in different designs. & 65 & 4.0462 & .92586 \\
\hline 3 & Orange is constantly improving its products. & 65 & 4.0154 & .96002 \\
\hline 4 & Orange is distinct in technology from its competitors. & 65 & 3.8000 & 1.20156 \\
\hline 5 & Orange product designs attract me very much. & 65 & 3.6154 & 1.54811 \\
\hline 6 & Orange products vary from product to product. & 65 & 3.5385 & 1.21291 \\
\hline 7 & Orange is a pioneer in introducing new products. & 65 & 3.4769 & 1.32415 \\
\hline 8 & Orange continues in expanding its markets. & 65 & 3.4462 & 1.33499 \\
\hline & General mean & 3.76 & 1.376 \\
\hline
\end{tabular}

Source: Prepared by researchers based on SPSS.V22 outputs 
Table (1) above shows the mean and standard deviation values of the innovation in the product dimension. By reviewing the results we note that the respondents valued highly orange's work on the development, and innovation of its products, with a general mean of (3.76) and standard deviation of $(1.376)$.

Table (2): Mean and the standard deviation of the innovation in the price dimension

\begin{tabular}{|c|l|c|c|c|}
\hline no & statement & $\begin{array}{c}\text { No of } \\
\text { respondents }\end{array}$ & Mean & $\begin{array}{c}\text { Standard } \\
\text { Deviation }\end{array}$ \\
\hline 9 & Orange product prices are commensurate with its products quality. & 65 & 4.3538 & 1.00671 \\
\hline 10 & $\begin{array}{l}\text { Orange products prices are suitable for their customers (compatible with } \\
\text { their purchasing power). }\end{array}$ & 65 & 4.3077 & 1.04468 \\
\hline 11 & $\begin{array}{l}\text { Orange sets new and innovative products prices that allow customers to } \\
\text { prefer them than competitors ones. }\end{array}$ & 65 & 3.1692 & 1.26946 \\
\hline 12 & Orange reduces its products prices from time to time. & 65 & 3.1563 & 1.25000 \\
\hline 13 & Orange sets attractive prices for its consumers. & 65 & 2.8462 & 1.24035 \\
\hline 14 & Orange determines its prices of products on the demand basis & 65 & 2.7846 & .94360 \\
\hline 15 & $\begin{array}{l}\text { Orange uses group pricing method, so that when buying several units, or } \\
\text { several items, the price will be less than buying one unit, or one item. }\end{array}$ & 65 & 2.7846 & 1.29292 \\
\hline 16 & Orange relies on customers views in pricing its products & 65 & 2.6000 & 1.14291 \\
\hline & General mean & & 3.25 & 1.313 \\
\hline
\end{tabular}

Source: Prepared by researchers based on SPSS.V22 outputs

Table (2) above shows the mean and standard deviation of the innovation in the price dimension. By reviewing the results we note that the respondents valued highly orange's innovation in price dimension, with a general mean of (3.25) and standard deviations of (1.313).

Table (3): Mean and standard deviation of the innovation in the promotion dimension

\begin{tabular}{|c|l|c|c|c|}
\hline no & statement & $\begin{array}{c}\text { No of } \\
\text { respondents }\end{array}$ & Mean & $\begin{array}{c}\text { Standard } \\
\text { Deviation }\end{array}$ \\
\hline 17 & Orange follows modern methods in promoting its products. & 65 & 4.4000 & .93207 \\
\hline 18 & Orange TV commercials are distinct. & 65 & 4.3385 & 1.01976 \\
\hline 19 & $\begin{array}{l}\text { Orange has a clear and comprehensive website contains all necessary } \\
\text { information. }\end{array}$ & 65 & 4.2923 & .82392 \\
\hline 20 & Orange is constantly updated its web- site. & 64 & 4.2813 & .99950 \\
\hline 21 & $\begin{array}{l}\text { In her commercials, Orange uses texts that have a comfortable } \\
\text { psychological effect. }\end{array}$ & 65 & 4.2308 & .76586 \\
\hline 22 & $\begin{array}{l}\text { Orange has pages on various social } \\
\text { media networking (Face book, twitter. }\end{array}$ & 65 & 4.1846 & .98254 \\
\hline 23 & Orange offers distinctive gifts in competitions. & 65 & 4.1846 & .99832 \\
\hline 24 & Orange sponsors several charitable programs. & & 4.25 & .88171 \\
\hline & General mean & 1.058 \\
\hline
\end{tabular}

Source: Prepared by researchers based on SPSS.V22 outputs

Table (3) above shows the mean and standard deviation values of the innovation in the promotion dimension. By reviewing the results we note that the respondents valued highly orange's innovation in promotion, with a general mean of(4.25)and standard deviation of (1.058). 
Table (4): Mean and standard deviation of the innovation in the distribution dimension.

\begin{tabular}{|c|c|c|c|c|}
\hline no & statement & $\begin{array}{c}\text { No of } \\
\text { respondents }\end{array}$ & Mean & $\begin{array}{l}\text { Standard } \\
\text { Deviation }\end{array}$ \\
\hline 25 & $\begin{array}{l}\text { Orange has lots of sales points that enables me to acquire its products } \\
\text { wherever i am. }\end{array}$ & 65 & 3.0154 & 1.24364 \\
\hline 26 & orange stores are located nearby the residential locations & 64 & 2.9375 & 1.29560 \\
\hline 27 & Orange sales points sellers behave in a good and friendly manner & 62 & 2.7258 & 1.33268 \\
\hline 28 & $\begin{array}{l}\text { Orange relies heavily on social media sites in the introduction of its } \\
\text { products. }\end{array}$ & 65 & 2.6769 & 1.04743 \\
\hline 29 & $\begin{array}{l}\text { Orange sales points offers the right atmosphere and Psychological } \\
\text { comfort for customers }\end{array}$ & 64 & 2.5938 & 1.30589 \\
\hline 30 & orange uses both telephone and e-mail for selling its products & 64 & 2.5000 & 1.32137 \\
\hline & General mean & & 2.74 & 1.509 \\
\hline
\end{tabular}

Source: Prepared by researchers based on SPSS.V22 outputs

Table (4) above shows the mean and standard deviation values of the innovation in the distribution dimension. By reviewing the results we note that the respondents valued highly orange's innovation in the distribution dimension, with a general mean of (2.74) and standard deviations of (1.509).

\subsection{Orange Jordan Telecom value creation for Customers}

Table (5) below, shows, the mean and standard deviation of the respondents' responses in terms of customer value creation statements, in descending order.

Table (5): Mean and standard deviation of the customer's value creation statements

\begin{tabular}{|c|c|c|c|c|}
\hline no & statement & $\begin{array}{c}\text { No of } \\
\text { respondents }\end{array}$ & Mean & $\begin{array}{l}\text { Standard } \\
\text { Deviation }\end{array}$ \\
\hline 31 & Orange products are of high quality & 65 & 3.1692 & 1.26946 \\
\hline 32 & Orange products are easy to use & 64 & 3.1563 & 1.25000 \\
\hline 33 & Orange products are available in all places & 65 & 3.0615 & 1.26091 \\
\hline 34 & Orange products lifetime is long & 65 & 3.0308 & 1.35749 \\
\hline 35 & I'm attracted to Orange products advertising & 65 & 2.9538 & 1.25537 \\
\hline 36 & The product lifetime is long & 64 & 2.9063 & 1.46622 \\
\hline 37 & $\begin{array}{l}\text { My use of orange products has brought me more benefits than the } \\
\text { amount of money i paid. }\end{array}$ & 64 & 2.9063 & 1.39976 \\
\hline 38 & Orange's products often correspond to my expectations. & 64 & 2.9062 & 1.34186 \\
\hline 39 & I buy orange products because their prices are suitable. & 63 & 2.8730 & 1.21140 \\
\hline 40 & I don't waste too much time to get orange products & 64 & 2.7500 & 1.19523 \\
\hline 41 & I don't make much effort to get orange products. & 63 & 2.6984 & 1.42144 \\
\hline 42 & I don't afford a high cost to have one of orange products & 64 & 2.6719 & 1.34583 \\
\hline 43 & Getting Orange products does not require a lot of procedures & 65 & 2.5231 & 1.27607 \\
\hline & General mean & & 2.89 & 1.420 \\
\hline
\end{tabular}

Source: Prepared by researchers based on SPSS.V22 outputs

Table (5) above shows the mean and standard deviation values of the customer's value creation dimension. By reviewing the results we note that the respondents valued highly orange's customers' value creation, with a general mean of (2.89) and standard deviations of (1.420). 


\subsection{Testing hypotheses}

Table (6): Shows the results of multiple regression analysis to test the impact of innovative marketing dimensions on the value creation of Orange Jordan Telecom customers'.

Table (6): Results of multiple regression analysis

\begin{tabular}{|l|c|c|c|c|c|}
\hline Models & $\mathrm{B}$ & Std.Error & Beta & $\mathrm{T}$ & Sig \\
\hline Innovative marketing & .406 & .105 & .934 & 3.882 & .000 \\
\hline Innovation in product & .576 & .146 & .764 & 3.935 & .000 \\
\hline Innovation in price & .346 & .123 & .563 & 2.803 & .008 \\
\hline Innovation in promotion & 3.042 & .143 & .227 & 21.348 & .034 \\
\hline Innovation in distribution & .252 & .138 & .572 & 1.827 & .042 \\
\hline
\end{tabular}

Source: Prepared by researchers based on SPSS.V22 outputs

By analyzing the results shown in table (6) above, we conclude that innovative marketing, as an independent variable, has an impact on creating value for Orange's Jordan Telecom customers at a level of significance (o.oo), which is less than the significance level (0.05). Thus we reject the main null hypothesis and accept alternate one which stated: There is a statistically significant impact of innovative marketing on creating value for Orange's Jordan Telecom customers.

The detailed impact of each dimension of innovative marketing on customer value creation can be derived from Table (6) as follows:

- With regard to the first sub- hypothesis and through the results shown in the table above, we conclude that innovation in orange's products has an impact on creating value for Orange's Jordan Telecom customers, at a level of significance (o.oo), which is less than the significance level (o.05). Thus we reject the null hypothesis and accept the alternate one which stated: There is a statistically significant impact of innovation in the product on creating value for Orange's Jordan Telecom customers.

- With regard to the second sub- hypothesis and through the results shown in the table above, we conclude that innovation in orange's prices has an impact on creating value for Orange's Customers at a level of significance (.oo8), which is less than the significance level (0.05). Thus we reject the null hypothesis and accept alternate one which stated: There is a statistically significant impact of innovation in price on creating value for Orange's Jordan Telecom customers.

- With regard to the third sub- hypothesis and through the results shown in the table above, we conclude that innovation in orange's promotion has an impact on creating value for Orange's Customers at a level of significance (.034), which is less than the significance level (0.05). Thus we reject the null hypothesis and accept alternate one which stated: There is a statistically significant impact of innovation in promotion on creating value for Orange's Jordan Telecom customers.

- With regard to the fourth sub- hypothesis and through the results shown in the table above, we conclude that innovation in orange's distribution has an impact on creating value for Orange's customers at a level of significance (.042), which is less than the significance level (o.05). Thus we reject the null hypothesis and accept alternate one which stated: There is a statistically significant impact of innovation in distribution on creating value for Orange's Jordan Telecom customers. 


\section{Results, Discussion, Conclusions and Recommendations}

\section{$15.1 \quad$ Results}

The most important results of the study can be summarized as follows:

1. There is a statistically significant impact of innovative marketing on creating value for Orange's Jordan Telecom customers (Table 6).

2. There is a statistically significant impact of innovation in the product on creating value for Orange's Jordan Telecom customers (Table 6).

3. There is a statistically significant impact of innovation in price on creating value for Orange's Jordan Telecom customers (Table 6).

4. There is a statistically significant impact of innovation in promotion on creating value for Orange's Jordan Telecom customers (Table 6).

5. There is a statistically significant impact of innovation in distribution on creating value for Orange's Jordan Telecom customers (Table 6).

\subsection{Discussion}

The significance of the results of this study give us clear guidance about the importance of innovative marketing, as a new marketing concept for organizations in adopting customer-oriented strategies, interested in meeting customer's needs and desires, and create value to them through innovative marketing dimensions (innovation in product, innovation in price, innovation in promotion, innovation in distribution) and methods used by each one of the four dimensions in achieving customer value creation as a central issue in the existence of any organization, since it helps in retaining its customers, to increase its market share, and to compete successfully through producing and delivering desirable goods and services, and to anticipates and detect new and even latent needs that customers can't express by providing and achieving solutions the customer did not think for.

\section{$15 \cdot 3$ Conclusions}

Innovative Marketing is of great importance to organizations that use it since it achieves a distinct competitive advantage of the organization by distinguishing its mental image, reputation, from other competitor's mental image and reputation which leads to positive results of the organization in maintaining or increasing its market share, increasing its sales, profits and the possibility to reach the center of market leadership, gain and attract new customers and retain existing customers, through its impact on customer's value creation by achieving customer's benefits, which may take the form of satisfying needs that were not saturated or satisfied before, satisfying current needs better than before, and saving on expenses. Researchers of this paper encourage both: the readers to learn more and more about innovative marketing, and researchers to conduct additional future researches and analysis in this area.

\subsection{Recommendations}

Researchers presented a set of recommendations that can be summarized as follows:

1. Orange has to pay attention to the marketing side, continue to improve its products and look for ways of innovation, that link the company with its customers.

2. Activating Orange social media sites, since social media nowadays are considered both mass and personal media to communicate with customers and to inform them about its new and innovative products.

3. To give great importance to innovation in all marketing mix elements, because achieving an effective marketing mix for Orange products increases customer's interest in its products 
and influences their purchasing decision.

4. Orange must pay more and more attention to its customers, work, and strive to create value for them by anticipating what products exceed their expectations or at a minimum, meet and achieve their expectations, to gain their loyalty.

\section{References}

Abdul Hamid, T., (2010) Innovative Marketing, Dar Al Fajr, Egypt.

Abo Bezah, A., (2015). Investigating the Relationship between Quality of Service, CustomerSatisfaction and Customer Value: A Comparative Study between Islamic and Commercial Banks in Jordan,unpublished master thesis, Business department, middle east university, Amman, Jordan.

Abu Jumaa N.,(2011) Innovative Marketing, Second Edition, Publications of the ArabOrganization for Administrative Development, League.

Al-Dowa, A., \& Al-Muhtadi, Munther, K,, (2015)"Innovation in the Promotion of Sports Activities and Events, Journal of Innovation and Marketing, University of Sidi Be Abbes, Second Issue, Algeria, p.13.

Al Obeidi, A. (2009) Organizational learning tools and their role in the adoption of innovative marketing skills (a survey of the views of a sample of the directors of the General Company of Southern Cement, $\mathrm{Al}$ Ghari Journal of Economic and Administrative Sciences, Volume 2, Issue 13.

Al-Taei, H.\&Alalak, B.s, (2008), Product Development and Pricing, Dar Al Yazuri Publishing and Distribution, Arabic Edition, Amman, Jordan.

Amjadal, A. (2011) Innovative Marketing and its role in promoting the performance of the economicestablishment: Case study of Sidi El Kabir for soft drinks in Balida - Algeria, Journal of Economic andAdministrative Research, 1oth Issue, Faculty of Economic, Commercial and Management Sciences, University of Mohammed Khaidr, Biskra.

Buraq, M.\&Lahrash, T.,(2016) "Modern Trends and Marketing Innovation in Banking: Lessonsof Success and Failure", p. o1, available at http://www.elbassair.net/. Browsing was done on 11/11/2018.

Hill,C. \&, Jones,G. (2010)"Strategic Management: An Integrated Approach", gth Edition, Mifflin Company,USA, P: 224.

Jafour, K. (2016) Innovative Marketing and its role in improving marketing performance in the serviceinstitution: The Case of al- alif hotel in Ouargla province, un published master thesis, Department ofCommercial Sciences, Faculty of Economic, Commercial , and Management Sciences,University of Qasidi, Algeria.

Jalab, I.\&Khalidi, N. (2013) Management of internal partnership and their Impacton customer value: An analytical study of a sample of employees views in General Company for RubberIndustries, Diwaniyah, Qadisiyah Journal of Administrative and Economic Sciences, Volume 16, Issue 4.

Kotler, P., Kevin, K., Delphine, M. \&Dubois, B. (2009).Marketing Management, Pearson Education, 13th Edition, France

Kotler, P.,(2004) Kotler talks about marketing: How to Create, Win and Dominate Markets,translated byFaisal Abdulla Babeker, third edition,2004, Jarir Library, Riyadh, saudia Arabia.

Kotler, P.\& Dubois, B. (2003) Marketing Management, French edition by Delphine Maunceau, 11th edition, Pearson, Pari

Lahul, S.\&Ayatt Allah, M.(2017) Innovation in the marketing mix is a source of competitive advantage in business organizations, Journal of Industrial Economics No. $12-2$.

Lahul, S., (2008), Marketing and Competitive Advantages: A Case Study of the Pharmaceutical Industry in Algeria, PhD Thesis, Al-Haj Al-Khader University.

Lambin, J. (2009)"le Marketing Stratigique", zeme édition, Ediscience International, Paris, France, P,281.

Madah, A.; Azouz, M.(2018) Promotional innovation and its role in creating value to the customer: Case study of the Algerian mobile phone company (Ooredoo),Journal of the Arab Accountant, volume46, September 2018

Mahaabat, A. (2009) "The implications of marketing innovation on the methods used to promote hotel marketing services, a field study in a number of hotels in the province of Erbil "Iraqi Journal of Administrative Sciences, No. 23, p. 264.

Michael,E.; Kostas, G.,(2014)Marketing Innovation, The Innovation Challenge, Creative TrainerModule, Nottingham Trent University, Nottingham Business School, , P: 12,13.

Nagasimha, B., (2015) Innovation and product innovation in marketing strategy, Journal ofManagement and marketing research, Vol 18. 
Owsu, K, (2010)The Role of Market Knowledge in Achieving Marketing Innovation (A Surveying Study in a number of Tourist Organizations in Dohuk City), Al-Rafidain Development Journal, Volume 31, No. 22, Faculty of Management and Economics, University of Mosul, Iraq

Raqeeck,Z. (2016)The Effect of Innovative Marketing on the Quality of Banking Services: Case Study of Gulf Bank Algeria - AGB Messila Agency, un published master thesis, business sciences department, faculty of Economic, Commercial and Management Sciences, Mohammed Khaydar University - Biskra, Algeria.

Rober, t A. Pitts\& David, L., (2005), Building and sustaining Competitive Advantage, South-Western College Pub; $4^{\text {th }}$,edition.

Shukal, A,; Rahimi, S, \& Zamouri, K., (2015) The role of the new products development of inactivating the competitive advantage of the economic institution, the fourth international forum on competition and competitiveness strategies for industrial establishments outside the hydrocarbons sector in the Arab countries, Faculty of Economic and Commercial Sciences and Management Sciences University of Chlef, Algeria, P. 4, see it on the sitehttp://labocolloque5.voila.net/84choukaleabdlkarim.pdf, At 8 pm. 11/23/2018.

Tawfiq, R. \& Maala, N., (2009) Principles of Marketing, United Arab Marketing and Supply Company, Egypt 